\title{
The effect of school performance upon marriage and long- term reproductive success in 10,000 Swedish males and females born 1915-1929
}

\author{
Anna Goodman, ${ }^{1}$ Ilona Koupil ${ }^{2}$ \\ 1 Department of Epidemiology and Population Health, London School of \\ Hygiene and Tropical Medicine, UK \\ 2 Centre for Health Equity Studies (CHESS), Stockholm University/Karolinska \\ Institute, Sweden
}

Corresponding author: Prof Ilona Koupil, Centre for Health Equity Studies (CHESS), Stockholm University/Karolinska Institute, SE-10691 Stockholm, Sweden. Email address: ilona.koupil@chess.su.se

Note: this is a personal version, created by Anna Goodman, of the text of the accepted journal article. It reflects all changes made in the peer review process, but does not incorporate any minor modifications made at the proof stage. The complete citation for the final journal article is:

- Goodman, A; Koupil, I; (2010) The effect of school performance upon marriage and long-term reproductive success in 10,000 Swedish males and females born 1915-1929 Evol Hum Behav, 31 (6). pp. 425-435

- DOI: 10.1016/j.evolhumbehav.2010.06.002

Copyright (C) and Moral Rights for this paper are retained by the individual authors and/or other copyright owners 


\begin{abstract}
$\underline{\text { Abstract }}$
Humans are an exceptionally intelligent species, and the selective pressures which may have shaped these advanced cognitive powers are therefore of interest. This study investigates the fitness consequences of pre-reproductive school performance in a Swedish population-based cohort of 5244 males and 4863 females born 1915-1929. School performance was measured at around age 10 using three variables: mean schoolmarks; being promoted/held back in school; and recognised learning difficulties. Our primary outcomes were probability of ever marrying, total number of children and total number of grandchildren. In males (but not females), poorer school performance predicted fewer children and grandchildren. This was primarily mediated via probability of marriage; mortality and fertility within marriage were not important mediating pathways. The effect of school performance upon marriage in males was independent of early-life social and biological characteristics, including birthweight for gestational age, preterm birth, family composition and family socio-economic position. The effect of school performance upon the probability of marriage in males was, however, largely mediated by adult socioeconomic position. This suggests that in general sexual selection for cognitive abilities per se did not play a major role in either males or females in this cohort. Adult socio-economic position did not, however, fully explain the marriage disadvantage in males or (at marginal significance) females with particularly poor school performance. We conclude that school performance can affect long-term reproductive success. In this population, however, the effect is confined to males and is largely mediated by the increased probability of marriage which comes with their greater socio-economic success.
\end{abstract}

\title{
Introduction
}

Multiple factors influence how well a child performs academically in school. The most important of these is generally the child's cognitive ability, which is highly correlated with school performance at all ages (0.4-0.7) and particularly in elementary school ${ }^{1-4}$. Other important influences include school attendance, the child's personality and motivation, and the degree of parental support and encouragement ${ }^{4,5}$. School performance is therefore predicted by early-life biological characteristics like birthweight which influence cognitive development ${ }^{6,7}$. School performance is also predicted by early-life social characteristics such as family composition or family socio-economic position which influence both cognitive development and also parental investment in a child's education ${ }^{8,9}$.

In many societies, school performance then in turn has profound implications upon a child's later life. In high-income countries it is an important gatekeeper to subsequent academic and vocational opportunities, and therefore a key predictor of achieved adult socio-economic position e.g. ${ }^{1,10,11}$. Socio-economic position in turn is strongly associated with health and survival across the lifecourse. ${ }^{12,13}$ Education continuation and adult socio-economic position are also associated with reproductive behaviours, albeit in ways which show more variation between populations and between men and women. Specifically, while a strong positive correlation between socio-economic position and number of offspring has consistently been reported in traditional and hunter-gatherer populations ${ }^{14,15}$, this association became more variable in modern populations 16,17 . For twentieth century women in particular, those who 
entered higher education and/or had high-status jobs typically married and had children later, and also frequently had smaller completed family sizes ${ }^{18-20}$.

These mortality and fertility effects imply that school performance may have direct implications for an individual's Darwinian fitness. Darwinian fitness refers to an individual's long-term genetic contribution to future generations ${ }^{21}$, and is frequently proxied by measures of reproductive success such as number of surviving children or grandchildren. School performance may also be associated with fitness by virtue of its close association with characteristics such as cognitive abilities. Within the field of evolutionary biology, research into cognitive abilities has focussed particularly upon sexual selection - that is, the component of natural selection which results from some individuals attracting more mates or better quality mates than others 22. Sexual selection for cognitive abilities has, in turn, been hypothesised to be an important mechanism underlying the evolution of humans' exceptional intelligence as a species ${ }^{23}$.

That both men and women say intelligence is very important to them in potential partners has been supported by studies of stated mate preferences from around the world. For example, in a study by Buss ${ }^{24}$ of over 10,000 individuals from 33 countries, both men and women ranked 'intelligence' as the second most important trait in a potential partner. The centrality of intelligence in stated mate preferences has since been replicated many times ${ }^{25-28}$ including in one study of American women's responses to videos of real men ${ }^{29}$. Yet few of these studies actually measured cognitive abilities and none examined actual mate choices. To our knowledge, only one longitudinal study in New Zealand has examined the relationship between childhood cognitive abilities (age 8-9) and later sexual behaviours ${ }^{10}$. This found that higher childhood intelligence predicted fewer sexual partners in the late adolescence after adjusting for multiple other characteristics including child mental health, family conflict and family socio-economic adversity. By contrast, childhood intelligence was not associated with number of sexual partners in young adulthood; the study cohort was too young to examine effects at older ages.

It is thus unknown whether individuals with higher cognitive abilities differ in their actual, long-term mating success, or how far any such effect is mediated by achieved socio-economic position. Moreover, several studies from high-income countries, suggest women of higher cognitive abilities and/or school performance have lower rates of teenage pregnancy in New Zealand; ${ }^{10}$, later first births in the USA; ${ }^{30}$ and smaller total family size in the USA; ${ }^{31,32}$. Evidence is conflicting on how far this is mediated by adult education, which as discussed above is often associated with reduced fertility in women in high-income countries. In addition, much less is known about the magnitude and mediators of any relationships in men.

\subsection{Hypotheses and research questions}

To summarise, it is plausible that school performance may predict long-term reproductive success in modern Western populations, but the relative contribution of mortality, mating and fertility pathways is unknown. It is also possible that these effects will sometimes operate in different directions or in different ways in men and women. Specifically, in men better school performance may increase survival, increase mating success and increase fertility. Adult socio-economic position may 
partly mediate these effects, but would not be expected to mediate them fully if cognitive abilities have an independent effect upon mate choice. In women, better school performance may again increase survival and increase the woman's attractiveness as a potential mate. This may, however, be partly or fully offset by a reduction in achieved fertility, as mediated by an increased probability of education continuation. Finally, in both sexes it is plausible that school performance may itself partly mediate the association between early-life social and biological characteristics and adult reproductive success. Such mediation could reflect the operation of both 'cognitive development' and/or 'parental investment pathways'.

Investigating these hypotheses can clarify the determinants of reproductive success in a particular context, and may also shed light onto plausible selective pressures in other societies or in our evolutionary past. Such investigations are challenging, however, because few studies have data on school performance and also on later-life mortality, fertility and long-term reproductive success. In addition, very few studies have been able to examine how far any observed effects of school performance are confounded or mediated by other characteristics across the lifecourse. We had the unique opportunity to redress these limitations in over 10,000 Swedish infants born 1915-1929 and followed across their lives. All our subjects had measures of pre-reproductive school performance collected at around age 10. In this cohort, we have previously demonstrated that social and biological characteristics at birth predict school performance and entrance to higher education (Unpublished data under submission: A. Goodman, M. D. Gisselmann, I. Koupil). We have also previously shown that characteristics at birth and higher education both predict subsequent marriage and reproductive success ${ }^{33}$. In this paper we therefore address the following research questions: 1) Is school performance associated with subsequent marriage and/or reproductive success (completed number of children and grandchildren)? 2) Do these effects differ between males and females? 3) How far are any effects of school performance mediated by achieved education or income in adulthood? and 4) How far does school performance itself mediate the previously-reported effects of characteristics at birth upon marriage and reproductive success?

\subsection{Historical context: enforced sterilisation in twentieth century Sweden}

The historical context of our study cohort deserves special mention. Between 1935 and 1975 some 63,000 individuals were sterilised in Sweden, over 95\% of whom were women ${ }^{34,35}$. While somewhat over half of these sterilisations were voluntary, a substantial minority reflected the application of laws permitted compulsory sterilisation. These circumstances included mental retardation, and "feeblemindedness" was used as a justification for compulsory sterilisation until the 1950s (M. Runcis, personal communication).

It is difficult to know how many individuals in our 1915-1929 birth cohort will have been affected by these sterilisation laws. On the one hand, it has been reported that sterilization rates were no higher in Uppsala than other parts of Sweden ${ }^{36}$. Moreover, it is worth noting that the majority of sterilisations performed on the grounds of "feeble-mindedness" in fact referred to socially marginal women with deviant sexual behaviour, such as unmarried working class girls seeking abortions (M Runcis, personal communication). Nevertheless, less intelligent women may plausibly have been particularly vulnerable to such compulsory sterilisations or to being coerced into 
'voluntary' sterilisations. It is therefore important to bear compulsory sterilisation in mind as a possible source of reduced fertility among female cohort members with the lowest cognitive abilities.

\section{Methods}

\subsection{Study population}

Our study sample is drawn from the Uppsala Birth Cohort (UBCoS), which comprises all 14,193 live births at the Uppsala University Hospital from 1915 to 1929. Of these, 13,811 (97.3\%) individuals were successfully traced through parish archives until death, emigration or until being assigned a unique personal registration number, usually in $1947^{37}$. In the current analysis, we focus upon individuals who survived to reproductive age (operationalised as age 15) and who lived in Sweden long enough to make it likely that all their children would be registered there. As summarised in Fig. 1, we therefore excluded all cohort members who were not traced after discharge from the maternity hospital (2.7\%), died aged 0-14 (9.7\%), or permanently emigrated before age $60(1.0 \%)$.

Using parish archives, we successfully traced the third grade school records for $10,107 / 12,283(82.3 \%)$ of the remaining eligible cohort members (5244 males, 4863 females). These 10,107 individuals form the study population for this paper. Of these, $9952(98.5 \%)$ remained alive and resident in Sweden long enough to be assigned personal numbers. As described below, we linked these individuals to registry data from across their lives, including number of biological children and grandchildren up to 2002 .

The study was approved by the regional ethics committee in Stockholm. 
Figure 1: Study population for analyses

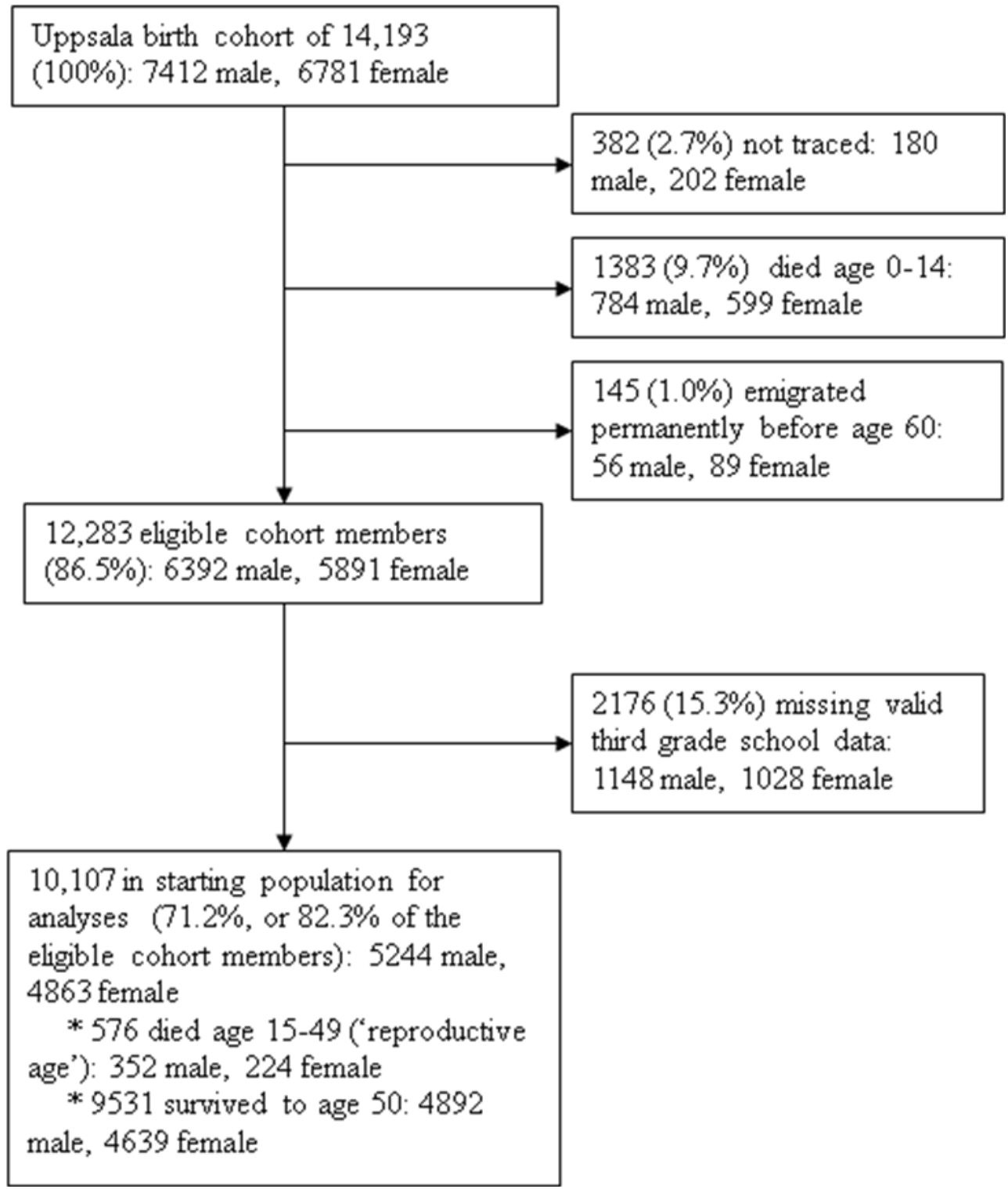

\subsection{Conceptual model and variables for analyses}

\subsubsection{Characteristics at birth}

To investigate the relationship between school performance and reproductive success we adopted the hierarchical conceptual model shown in Fig. 2. Information on social and biological characteristics at birth was obtained from archived obstetric records. As presented in Table 1, these characteristics were standardised birthweight for gestational age; preterm birth; birth multiplicity; birth order; mother's age; mother's marital status; and family social class. We calculated birthweight for gestational age by standardising birthweight on a week-by-week basis, standardising separately for males and females details in ${ }^{33}$. Family social class was coded using the Swedish socio-economic classification scheme SEI: ${ }^{38}$. We used father's occupation if recorded or mother's occupation if not. None of the characteristics at birth were associated with gender $(\mathrm{p}<0.01)$. 
Figure 2: Conceptual model for analyses

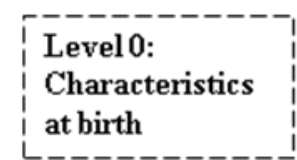

\begin{tabular}{|c|c|c|c|c|c|c|}
\hline $\begin{array}{c}\text { Bwt for } \\
\text { gest age }\end{array}$ & $\begin{array}{c}\text { Preterm } \\
\text { birth }\end{array}$ & $\begin{array}{c}\text { Birth } \\
\text { multiplicity }\end{array}$ & $\begin{array}{c}\text { Birth } \\
\text { order }\end{array}$ & $\begin{array}{c}\text { Mother's } \\
\text { age at birth }\end{array}$ & $\begin{array}{c}\text { Mother } \\
\text { married }\end{array}$ & $\begin{array}{c}\text { Family } \\
\text { social class }\end{array}$ \\
\hline
\end{tabular}

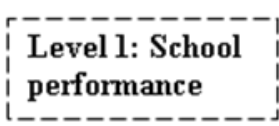

\begin{tabular}{|c|c|c|}
\hline $\begin{array}{c}\text { Third grade } \\
\text { schoolmarks }\end{array}$ & $\begin{array}{c}\text { Age in third } \\
\text { grade }\end{array}$ & $\begin{array}{c}\text { Recognised learning } \\
\text { difficulty }\end{array}$ \\
\hline
\end{tabular}

Apriori

confounder birth year

\section{Mortality between ages 15-49}

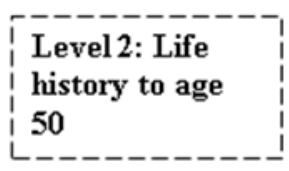

Highest education, 1960

\begin{tabular}{|c|}
\hline Highest education, 1960 \\
\hline Income (males only), 1970 \\
\hline Ever married by $1970 \uparrow$ \\
\hline
\end{tabular}

Level 3: No.

children

Total number of biological children

Level 4: No.

grandchildren

Total number of biological grandchildren

Abbreviations in Fig. 2: 'Bwt for gest age' = standardised birthweight for gestational age. $\dagger$ indicates our primary outcomes of interest. 
Table 1: Characteristics of 5244 males and 4863 females from the Uppsala Birth cohort (born 19151929; analyses restricted to those who survived to age 15 and did not permanently emigrate)

\begin{tabular}{|c|c|c|c|}
\hline Independent variables & Range/categories & \multicolumn{2}{|l|}{ Percentage } \\
\hline \multicolumn{4}{|l|}{ Early life characteristics } \\
\hline \multirow{5}{*}{$\begin{array}{l}\text { Standardised birthweight for } \\
\text { gestational age (standardised } \\
\text { separately by sex) }\end{array}$} & Quintile 1 (smallest), $\mathrm{n}=1,832$ & 18.6 & 18.8 \\
\hline & Quintile 2, $\mathrm{n}=1915$ & 19.7 & 19.3 \\
\hline & Quintile 3, n=1998 & 21.0 & 19.7 \\
\hline & Quintile 4, $n=2036$ & 19.8 & 21.8 \\
\hline & Quintile 5 (largest), $\mathrm{n}=2030$ & 20.9 & 20.5 \\
\hline \multirow[t]{2}{*}{ Preterm birth } & Term ( $\geq 37$ weeks), $n=9084$ & 92.2 & 92.5 \\
\hline & Pre-term ( $\leq 36$ weeks), $n=652$ & 7.8 & 7.5 \\
\hline \multirow{2}{*}{ Birth multiplicity } & Singleton, $\mathrm{n}=9837$ & 97.7 & 97.0 \\
\hline & Twin/triplet, $n=270$ & 2.3 & 3.0 \\
\hline \multirow[t]{4}{*}{ Birth order (mother's parity) } & $1, \mathrm{n}=3788$ & 37.6 & 37.3 \\
\hline & $2-3, n=3844$ & 37.3 & 38.8 \\
\hline & $4-5, n=1415$ & 14.5 & 13.5 \\
\hline & $6-18, n=1058$ & 10.6 & 10.4 \\
\hline \multirow[t]{6}{*}{ Mother's age at birth } & $15-19$ years, $n=529$ & 5.1 & 5.4 \\
\hline & $20-24$ years, $n=2630$ & 25.5 & 26.6 \\
\hline & $25-29$ years, $n=2850$ & 29.1 & 27.2 \\
\hline & $30-34$ years, $n=2132$ & 20.6 & 21.6 \\
\hline & $35-39$ years, $n=1357$ & 13.9 & 12.9 \\
\hline & $40-49$ years, $\mathrm{n}=605$ & 5.8 & 6.2 \\
\hline \multirow[t]{2}{*}{ Mother's marital status } & Ever married, $n=8339$ & 83.2 & 82.2 \\
\hline & Never married, $\mathrm{n}=1748$ & 16.9 & 17.8 \\
\hline \multirow{7}{*}{$\begin{array}{l}\text { Family social class } \\
\text { at birth }\end{array}$} & High/mediate non-manual, $\mathrm{n}=709$ & 7.4 & 7.0 \\
\hline & Low non-manual, $\mathrm{n}=669$ & 6.9 & 6.7 \\
\hline & Skilled manual, $n=1503$ & 15.0 & 15.6 \\
\hline & Semi or unskilled manual, $n=4660$ & 46.8 & 47.8 \\
\hline & Entrepreneur=328 & 3.49 & 3.15 \\
\hline & Farmer, $\mathrm{n}=1505$ & 15.8 & 14.7 \\
\hline & House son/daughter, $n=479$ & 4.7 & 5.1 \\
\hline \multicolumn{4}{|l|}{ Childhood characteristics } \\
\hline \multirow[t]{5}{*}{ Third grade schoolmarks $\dagger$} & Qunitle 1 (highest), n=2011 & 15.7 & 24.5 \\
\hline & Qunitle 2, n=2023 & 17.5 & 22.8 \\
\hline & Qunitle 3, $n=2025$ & 19.5 & 20.6 \\
\hline & Qunitle 4, n=2057 & 22.1 & 18.5 \\
\hline & Quintile 5 (lowest), n=1991 & 25.3 & 13.7 \\
\hline \multirow[t]{4}{*}{ Age in third grade $\dagger$} & $1-2$ years ahead, $n=259$ & 2.7 & 2.4 \\
\hline & Correct age, $n=8129$ & 78.4 & 82.9 \\
\hline & 1 year behind, $n=1501$ & 16.5 & 13.2 \\
\hline & $2-5$ years behind, $n=200$ & 2.4 & 1.5 \\
\hline \multirow{2}{*}{$\begin{array}{l}\text { Recognised learning } \\
\text { difficulty }\end{array}$} & No, $n=9991$ & 98.8 & 99.0 \\
\hline & Yes, $n=116$ & 1.2 & 1.1 \\
\hline \multicolumn{4}{|l|}{ Adult characteristics } \\
\hline \multirow[t]{2}{*}{ Survival to age $50 \dagger$} & No, $n=576$ & 6.7 & 4.6 \\
\hline & Yes, $n=9531$ & 93.3 & 95.4 \\
\hline & Elementary ( $\leq 10$ years $), n=8598$ & 87.1 & 95.6 \\
\hline \multirow{2}{*}{ (if survived to age 50) $\uparrow$} & Senior $(11-13$ years $), n=444$ & 7.1 & 2.2 \\
\hline & Post-senior $(\geq 14$ years $) n=377$ & 5.8 & 2.2 \\
\hline \multirow{6}{*}{$\begin{array}{l}\text { Net income, males only } \\
\text { (if survived to age 50) }\end{array}$} & $0-14,999 \mathrm{SEK}, \mathrm{n}=513$ & 10.6 & - \\
\hline & $15,000-24,999$ SEK, $n=673$ & 13.9 & - \\
\hline & $25,000-29,999$ SEK, $n=860$ & 17.7 & - \\
\hline & $30,000-34,999$ SEK, $n=880$ & 18.1 & - \\
\hline & $35,000-44,999$ SEK, $n=901$ & 18.6 & - \\
\hline & $45,000+$ SEK, $n=1026$ & 21.1 & - \\
\hline
\end{tabular}

SEK $=$ Swedish krona. $\dagger$ Evidence $(\mathrm{p}<0.001)$ of an association with sex. No other variables showed evidence of an association at the $1 \%$ level 


\subsubsection{Childhood school performance}

We used three measures of school performance: third grade schoolmarks, age in third grade, and recognised learning difficulty (see Table 1). All three were calculated from the spring term school records from the child's third grade of elementary school. Our first school performance measure was the child's mean schoolmarks across up to ten standard subjects. Subjects were marked using the grades $\mathrm{C}$ (lowest), $\mathrm{Bc}, \mathrm{B}, \mathrm{Ba}, \mathrm{AB}$, a and $\mathrm{A}$ (highest), with additional qualification with pluses and minuses. We coded these from 0 (grade C) to 18 (grade A) in accordance with the scoring system suggested by the education department in $1942{ }^{39}$. As some children were missing information on some subjects (mean of 0.9 subjects missing per child, range 0-4), we calculated an overall third grade average after standardising marks in each subject individually. Our second measure was the child's age in the third grade. In theory children complete the Swedish third grade in the year they turn 10 , but at this time it was relatively common for children to be promoted up or held back by one or more years. This was almost always on the grounds of ability ${ }^{40}$. Our final measure of school performance was whether the child had a recognised learning difficulty.

The Spearman's correlation of mean schoolmarks and age in third grade was 0.16. For both schoolmarks and age in third grade there was strong evidence $(\mathrm{p}<0.001)$ that females had better outcomes than males. There was no evidence of a sex difference for learning difficulties.

\subsubsection{Life history to age 50}

Mortality data was obtained from the Swedish death registry or, for those who died before being assigned a personal identification number, from parish archives. Linkage to the Swedish censuses of 1960 and 1970 provided information on highest educational level (1960) and net personal income (1970), banded as shown in Table 1. In 1970 our cohort members were 41-55 years old, at which ages annual and lifetime incomes were highly correlated in Swedish males in this time period ${ }^{41}$. By contrast, women at this time commonly stopped working when they got married ${ }^{42}$. We therefore did not use 1970 personal income when seeking to explain differences in the probability of marriage of our female cohort members. By contrast, we did feel able to use 1960 highest educational level in both sexes as this was usually achieved prior to marriage. The 1960 and 1970 Swedish censuses also provided information on marital status, which we used to determine whether cohort members had ever been married by 1970 .

\subsubsection{Number of children and grandchildren}

Total number of registered biological children and total number of registered biological grandchildren were obtained from the Swedish Multigenerational registry in 2002. To be included in the Multigenerational Registry, descendants had to be born in 1932 (i.e., when cohort members were aged 3-17 years) or later; and had to survive until at least $1961^{43}$. We have previously shown that missing data on parenthood was rare for these descendants, estimated at $2.3 \%$ for fathers and $0.4 \%$ in mothers (a further unknown fraction of the parenthood may be misattributed). We have also 
previously shown that by 2002 the number of children for this cohort was complete and the number of grandchildren was almost complete ${ }^{33}$.

\subsection{Statistical analysis}

The frequency of missing data for the variables presented in Fig. 1 ranged from 0\%-2.9\%. We used multiple imputation (five imputations) to impute missing values under an assumption of missing at random. Guided by our conceptual model, we then fitted linear and logistic regression models to examine the determinants of reproductive success and marriage. We adjusted all models for birthyear by one-year age band, and present p-values for heterogeneity for ordered categorical variables (age in third grade and income band). For descriptive univariable analyses and graphs, we divided our continuous schoolmarks measure into quintiles. All analyses were conducted in Stata 10.2.

To examine whether any observed effects were gender-specific, we tested all models for interactions between sex and all other characteristics at birth. This involved substantial multiple testing, as did our main effects analyses. We therefore concentrate upon findings which were replicated across our different measures of school performance.

\section{$\underline{\text { Results }}$}

\subsection{School performance and reproductive success}

As of 2002, 18,452 biological children and 34,089 biological grandchildren were registered for our 10,107 cohort members. The distribution for males and females was very similar, although males were more likely to have no children $(21.0 \%$ vs. $17.5 \%$ in women, $\left.\chi_{1}^{2}=20.0 \mathrm{p}<0.001\right)$ and no grandchildren $(27.6 \%$ vs. $23.8 \%$ in women, $\chi_{1}^{2}=19.0 \mathrm{p}<0.001$ ). Among those surviving to age $50,91.1 \%$ had married by 1970 and this proportion was again slightly lower in men $(89.7 \%$ vs. $92.7 \%$ in women, $\left.\chi_{1}^{2}=26.7 \mathrm{p}<0.001\right)$.

In general, univariable analyses indicated comparatively modest variation in these outcomes. Across most categories of school performance, the percentage ever married varied from $87 \%-93 \%$, the mean number of children varied from 1.70-2.10 and the mean number of grandchildren varied from 3.20-3.70. The main exceptions were males who had learning difficulties or who were two years or more too old for the third grade; in these groups the proportion ever married was under $75 \%$, the mean number of children was under 1.40, and the mean number of grandchildren was under 2.40 (full results in the Supplementary material).

Columns 1 and 2 of Table 2 present multivariable analyses of the relationship between school performance and reproductive success in the full study population. There was some evidence of independent effects for all three measures, such that individuals with poorer school performance had fewer children and grandchildren. In several instances there was evidence of an interaction with gender, and sex-stratified analyses revealed that in females the effects of school performance were weaker and were not statistically significant (see Supplementary Material for sex-stratified analyses). There was little change in these findings after restricting to those who 
survived to age 50 (columns 3 and 4 of Table 2), indicating that mortality was not an important mediator of these effects. By contrast, further restricting the analyses to those who ever married reduced the effect sizes substantially, rendering them marginally significant or non-significant. Restricting to those who ever married also eliminated all evidence of gender-interactions.

Table 2: Reproductive success among 5244 males and 4863 females from the Uppsala Birth cohort (born 1915-1929; analyses restricted to those who survived to age 15 and did not permanently emigrate)

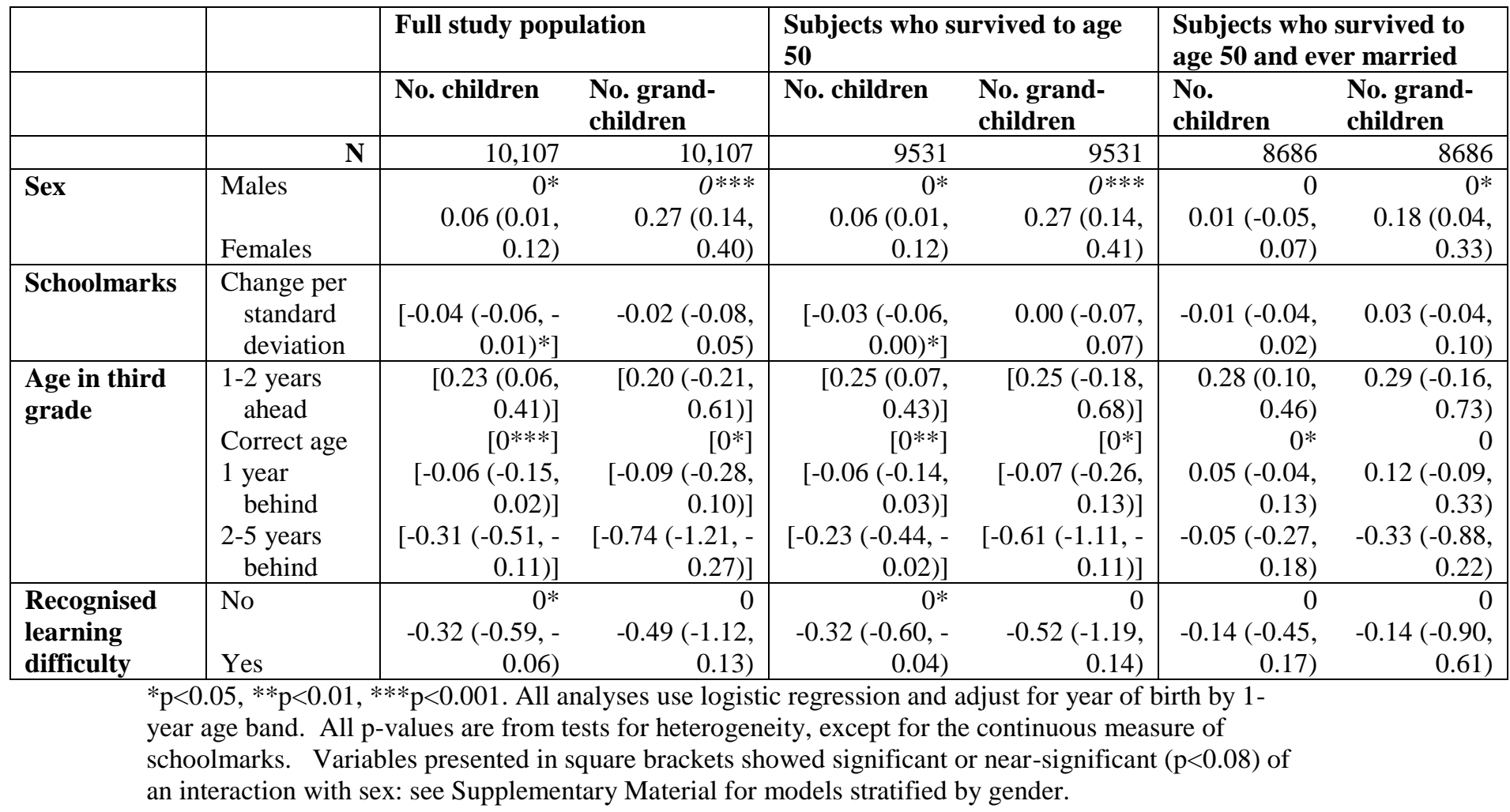

This central role of marriage was confirmed in logistic regression analyses predicting the probability of marriage among those who survived to age 50. All three school performance measures showed significant or borderline significant evidence of an interaction with gender ( $<<0.001$ for schoolmarks; $\mathrm{p}=0.001$ for age in third grade, and $\mathrm{p}=0.07$ for learning difficulties). In all cases, this interaction was such that there was strong $(\mathrm{p} \leq 0.002)$ evidence for an association in males but little or no evidence in females (Fig. 3 and Table 3). Only age in third grade showed marginal evidence of an effect in females $(\mathrm{p}=0.08)$, with a trend towards a lower probability of marriage among those who were two or more years behind the correct age (adjusted odds ratio 0.51; $95 \%$ CI 0.25 to 1.05 ). 
Figure 3: Effect of school performance upon the odds marriage among those who survived to age 50, stratified by gender
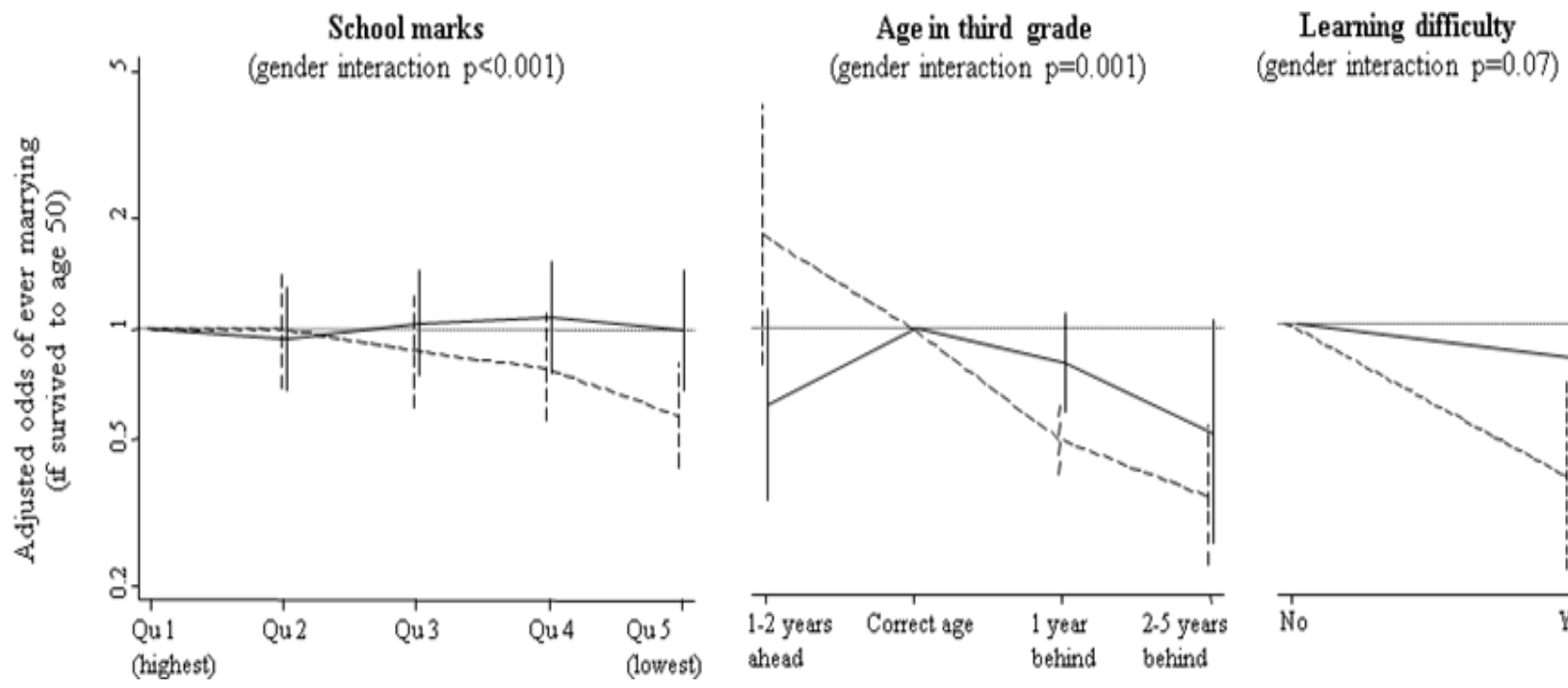

Models for each variable adjust for the other two, and also for year of birth. Full gender-specific models in the Supplementary Material.

Table 3: Effect of childhood cognitive abilities upon probability of ever marrying in 4892 males and 4639 females from the Uppsala Birth cohort (born 1915-1929; analyses restricted to those who survived to age 50 and did not permanently emigrate)

\begin{tabular}{|c|c|c|c|c|c|}
\hline & \multicolumn{3}{|l|}{ MALES } & \multicolumn{2}{|l|}{ FEMALES } \\
\hline & $\begin{array}{l}\text { Childhood } \\
\text { cognitive } \\
\text { abilities only }\end{array}$ & $\begin{array}{l}\text { Childhood } \\
\text { cognitive } \\
\text { abilities plus } \\
\text { adult education }\end{array}$ & $\begin{array}{l}\text { Childhood cognitive } \\
\text { abilities plus adult } \\
\text { education and } \\
\text { income }\end{array}$ & $\begin{array}{l}\text { Childhood } \\
\text { cognitive } \\
\text { abilities only }\end{array}$ & $\begin{array}{l}\text { Childhood } \\
\text { cognitive } \\
\text { abilities plus } \\
\text { adult education }\end{array}$ \\
\hline & 4892 & 4892 & 4892 & 4639 & 4639 \\
\hline $\begin{array}{l}\text { Change per standard } \\
\text { deviation }\end{array}$ & $0.79(0.71,0.88)^{* * *}$ & $\begin{array}{r}0.82(0.74 \\
0.91)^{* * *}\end{array}$ & $0.90(0.81,1.00)$ & $1.03(0.92,1.15)$ & $0.97(0.86,1.09)$ \\
\hline 1-2 years ahead & $1.80(0.79,4.14)$ & $1.38(0.59,3.21)$ & $1.08(0.45,2.62)$ & $0.60(0.33,1.12)$ & $0.94(0.49,1.80)$ \\
\hline Correct age & $1 * * *$ & $1 * * *$ & $1 * * *$ & 1 & 1 \\
\hline 1 year behind & $0.49(0.39,0.62)$ & $0.51(0.41,0.64)$ & $0.60(0.47,0.76)$ & $0.80(0.58,1.10)$ & $0.75(0.55,1.04)$ \\
\hline 2-5 years behind & $0.35(0.22,0.55)$ & $0.36(0.23,0.57)$ & $0.45(0.28,0.73)$ & $0.51(0.25,1.05)$ & $0.50(0.24,1.04)$ \\
\hline No & $1 * *$ & $1 * *$ & $1 *$ & 1 & 1 \\
\hline Yes & $0.40(0.22,0.71)$ & $0.40(0.23,0.72)$ & $0.49(0.26,0.90)$ & $0.81(0.31,2.14)$ & $0.78(0.29,2.05)$ \\
\hline Elementary & & $1 * *$ & 1 & & $1 * * *$ \\
\hline Senior & & $2.01(1.17,3.44)$ & $0.69(0.38,1.25)$ & & $0.30(0.18,0.52)$ \\
\hline Post-senior & & $2.21(1.14,4.29)$ & $0.66(0.31,1.41)$ & & $0.22(0.13,0.36)$ \\
\hline 0-14,999 SEK & & & $1 * * *$ & & \\
\hline 15,000-24,999 SEK & & & $1.88(1.43,2.47)$ & & \\
\hline 25,000-29,999 SEK & & & $3.66(2.73,4.91)$ & & \\
\hline 30,000-34,999 SEK & & & $5.60(4.04,7.76)$ & & \\
\hline 35,000-44,999 SEK & & & $8.90(6.12,12.94)$ & & \\
\hline $45,000+$ SEK & & & $21.17(12.18,36.80)$ & & \\
\hline
\end{tabular}

$* \mathrm{p}<0.05, * * \mathrm{p}<0.01, * * * \mathrm{p}<0.001$. All analyses use logistic regression and adjust for year of birth by 1year age band. All p-values are from tests for heterogeneity, except for the continuous measure of schoolmarks. SEK $=$ Swedish Krona. 


\subsection{Is the association between school performance and marriage mediated by adult education or income?}

We then examined how far the association between school performance and marriage was mediated by 1) highest achieved educational level in 1960 (both sexes) and 2) personal income in 1970 (males only). In males, adjusting for highest education level had relatively little effect. By contrast, adjusting for income reduced the effect sizes of all three school performance measures substantially (and, interestingly, also mediated the effect of higher education). Adjusting for income did not fully eliminate the marriage disadvantage to males who had been held back one or more years in school, however, or who had recognised learning difficulties. These results were almost identical when repeated using male income as a continuous variable, suggesting that residual confounding could not explain the persistent disadvantage in males with poor school performance.

In females, adjusting for the lower probability of marriage among women who attended higher education did not unmask any effect of school performance. Instead the relationship of school performance with marriage remained non-significant for all three measures, although there remained marginal evidence of a disadvantage to females who had been held back by two or more years in school.

\subsection{Do characteristics at birth explain the association between school performance and marriage?}

Lastly, we fitted sex-stratified models which used probability of marriage as the outcome and which 1) adjusted for characteristics at birth only, 2) adjusted for school performance only and 3 ) adjusted for both together. In no case did mutually adjusting for characteristics at birth and school performance result in any marked changes in the effects observed. Rather all point estimates were very similar and the substantive conclusions unchanged regarding the strong effect of school performance upon marriage in males and the absence of an effect in females (see Supplementary Material). This indicated that childhood school performance was not an important mediator of the effects of characteristics at birth on probability of marriage and, conversely, that the effects of school performance could not be explained in terms of the early-life characteristics. Rather these two sets of characteristics seem to have operated independently in this sample.

\section{Discussion}

This Swedish population-based cohort of 5244 males and 4863 females born 1915-1929 provides a uniquely detailed investigation of how school performance affects subsequent marriage and reproductive success in a modern population. In male (but not female) cohort members, there was evidence that poorer school performance predicted fewer children and grandchildren. This was primarily mediated via probability of marriage; mortality or fertility within marriage were not important mediating pathways. The effect of school performance upon marriage in males was independent of early-life social and biological characteristics, including birthweight, preterm birth family composition and family socio-economic position. The effect of 
school performance upon the probability of marriage in males was, however, largely mediated by adult socio-economic position. Adult socio-economic position did not, however, fully account for the disadvantage to males or (at marginal significance) females with particularly poor school performance.

\subsection{Strengths and limitations}

Our study has several strengths, including its large sample; its use of a welldefined population-based cohort with prospective data collection; and its use of 'gold standard' outcomes such as actual marriage and near-complete number of descendents in the third generation. It does, however, also have several important limitations. Some of these related to our exposure and outcome data. First, although national guidelines for assigning schoolmarks did exist, our three measures of school performance will to some extent reflect the judgements of individual teachers and schools. The resulting measurement error means we may have underestimated the effects of school performance. Nevertheless, the highly consistent findings across our three very different measures of school performance makes us believe that measurement issues cannot explain our substantive findings. Secondly, we lacked information on some potentially important early-life characteristics such as parental education. The effect of school performance upon reproductive success was, however, almost unchanged after adjusting for parent social class or marital status. This suggests that our findings cannot be explained by residual confounding of family socio-economic position. Thirdly, some descendants will be missing or inappropriately included in these because of incomplete coverage in the Multigenerational Registry. We have previously argued, however, that these effects are likely to be comparatively small and are unlikely to explain associations with early-life characteristics ${ }^{33}$.

Finally, despite the large sample size, some analyses were underpowered. This applied particularly to our investigation of the effect of poor school performance upon female marriage, the reduced power reflecting the fact that poor school performance was rarer among females while marriage was closer to universal. The result was that there was only marginal evidence that the 71 females who were 2-5 years behind in the third grade were less likely to marry, despite a large point estimate for this association $(\mathrm{OR}=0.51)$. While our analyses thus indicate that school performance did not predict marriage or reproductive success for females in the normal range, we are unable to rule out the possibility of such effects at the low extremes.

\subsection{Implications and directions for future research}

Given that cognitive abilities are the single strongest predictor of school performance $^{1,2,4}$, this paper sheds light onto the selective pressures upon cognitive abilities in twentieth century Sweden. It is, however, vital to stress that selective pressures in modern low-fertility populations may not generalise to traditional or ancestral populations ${ }^{44,45}$. For example, parental 'competence' may be an important predictor of offspring survival in high-infant mortality settings ${ }^{46}$. Under such circumstances, parent cognitive abilities might plausibly predict reproductive success in a way which was not apparent in our low-mortality population. Nor can it be assumed that the associations reported here will persist into the future. For example, in contrast to previous generations, more highly educated Swedish women are now 
$\underline{\text { more }}$ likely to intend to get married, to get married and to stay married ${ }^{47,48}$. Our findings therefore emphatically do not imply that school performance or cognitive abilities are only ever important predictors of reproductive success in men, or that this is only ever mediated via mate choice.

Nevertheless, the strong effect of school performance upon male (but not female) marriage does exemplify a potentially important mechanism whereby sexual selection may operate upon intelligence. Our study found that adult income was an important mediator of this association. This suggests that it may not primarily have been female preferences for cognitive abilities per se which increased the probability of marriage for more intelligent males, but rather female preferences for the higher earning available to more intelligent males. This interpretation is consistent with the evidence that while both men and women generally rank 'intelligence' as being among the most important characteristics in a potential mate, status and wealth are more important components of female mate preference than male mate preference e.g. ${ }^{24,25-}$ 27, 49. It is also consistent with studies from Britain, the US and Sweden which show 1) a positive association between education/income and overall reproductive success in males (but usually not females), and 2) that this association is explained by high socio-economic position males being more likely to marry and start a family ${ }^{50-52}$.

We therefore conclude that in this population cognitive abilities were largely an upstream rather than a direct determinant of males' probability of marriage. If this interpretation is correct, then one implication is that studies of stated mate preferences may not always yield the same findings as studies of actual mate choice. A further implication is that the magnitude of the effects of school performance or cognitive abilities upon mating success may vary across time and place in accordance with the degree to which individual abilities predict educational outcomes and adult socioeconomic success.

Yet adjusting for adult socio-economic position did not fully explain the disadvantage to males with particularly poor school performance. This might reflect the operation of other mediating pathways such as poorer adult health. Alternatively, particularly low cognitive abilities may have directly reduced males' chances of success in attracting a mate. Suggestively, the small group $(\mathrm{N}=71)$ of females who were two or more years behind in the third grade also showed marginal evidence of a lower probability of marriage, hinting at the possibility of such effects in both sexes. This would be consistent with some evidence from the USA indicating that both males and females apply minimum thresholds for intelligence when rating potential mates ${ }^{27}$. It is, however, also plausible that this marginal effect in females reflects the highly context-specific application of Sweden's sterilization laws. These laws permitted compulsory sterilisation for those with mental retardation ${ }^{34,35}$, with the vast majority of sterilisations being carried out upon women. It will therefore be of substantial interest to examine whether our findings are replicated in other lifecourse studies and, if so, how far any effects can be explained by other potential mediators such as health in adulthood.

A final notable finding of our study was that the effects of school performance upon marriage were independent of the previously-described effects of social and biological characteristics at birth ${ }^{33}$. This is of particular interest with regard to the effect of adverse birth outcomes upon probability of marriage in men. Previous 
studies have documented this association in this ${ }^{33,53}$ and other ${ }^{54}$ cohorts, and have suggested reduced cognitive abilities as one possible mechanism for this association. The analyses in this paper provide no evidence to support this hypothesis, however, as the effects of adverse birth outcomes were almost identical after adjustment for school performance. This indicates the need to explore other possible mechanisms for the effects of birth outcomes, such as reduced adult height. This study likewise provided no evidence to support 'parent investment in education' as being an key mediating pathway between early-life family social characteristics upon long-term reproductive success. Again, therefore, alternative mechanisms need to be investigated to explain this association.

\subsection{Conclusion}

In summary, this analysis of males and females born in Sweden in 1915-1929 demonstrates that pre-reproductive school performance can affect lifetime reproductive success in a post-demographic transition population. These effects were confined to males, however, and were primarily mediated via the probability of marriage. This builds upon our previous demonstration that the probability of marriage is a crucial component of reproductive success in this population, and that the early-life determinants of marriage are highly gender-specific ${ }^{33}$. We found that the effect of school performance upon male marriage was largely mediated by adult income. This suggests that in general sexual selection for cognitive abilities per se did not play a major role in either males or females in this cohort. Adult income could not fully account for the disadvantage seen to males at the extreme low end of the cognitive abilities distribution, however, suggesting a possible role for other mediators (e.g. adult health) or for direct mate choice. Greater understanding of these underlying mechanisms will enhance our ability to predict how far poor school performance and low cognitive ability may constrain individuals' social and reproductive success in other populations. This, in turn, may shed further light onto the type of environments in which these effects manifest themselves, and thereby clarify the selective pressures favouring the evolution of advanced human cognitive abilities in the past.

\section{Conflict of interest}

None

\section{$\underline{\text { Acknowledgements }}$}

Many thanks Bitte Modin, Lisa Holmberg, Lina Svensson, Isabelle Ljungkvist and Arijeta Makolli for their work in collecting the third grade school data; to Bitte Modin, Rawya Mohsen and Reidar Österman for their contribution to data management; and to Marit Gisselmann, Bitte Modin and Denny Vågerö for comments during preparation of this manuscript. UBCoS Multigen is supported by grants from the Swedish Council for Working Life and Social Research and the Swedish Research Council. IK is currently funded by the Swedish Council for Working Life and Social Research. 


\section{$\underline{\text { References }}$}

1. Jencks C. Who gets ahead?: The determinants of economic success in America. New York, NY: Basic Books; 1979.

2. Jensen AR. The g factor. Westport, Connecticut: Praeger; 1998.

3. Mackintosh NJ. IQ and Human Intelligence. Oxford: Oxford University Press; 1998.

4. Deary IJ, Strand S, Smith P, Fernandes C. Intelligence and educational achievement. Intelligence. 2007;35:13-21.

5. Petrides KV, Chamorro-Premuzic T, Frederickson N, Furnham A. Explaining individual differences in scholastic behaviour and achievement. British Journal of Educational Psychology. 2005;75(2):239-255.

6. Bhutta AT, Cleves MA, Casey PH, Cradock MM, Anand KJ. Cognitive and behavioral outcomes of school-aged children who were born preterm: a metaanalysis. JAMA. Aug 14 2002;288(6):728-737.

7. Shenkin SD, Starr JM, Deary IJ. Birth weight and cognitive ability in childhood: a systematic review. Psychol Bull. Nov 2004;130(6):989-1013.

8. Steelman L, Powell B, Werum R, Carter S. Reconsidering the effects of sibling configuration: recent advances and challenges. Annu Rev Sociol. 2002;28:243269.

9. Bradley RH, Corwyn RF. Socioeconomic status and child development. Annu Rev Psychol. 2002;53:371-399.

10. Fergusson DM, Horwood LJ, Ridder EM. Show me the child at seven II: Childhood intelligence and later outcomes in adolescence and young adulthood. J Child Psychol Psychiatry. Aug 2005;46(8):850-858.

11. Ceci SJ, Williams WM. Schooling, intelligence, and income. American Psychologist. Oct 1997;52(10):1051-1058.

12. World Health Organization. Closing the gap in a generation: health equity through action on the social determinants of health. Geneva: World Health Organization; 2008.

13. Davey Smith G, Hart C, Hole D, et al. Education and occupational social class: which is the more important indicator of mortality risk? J Epidemiol Community Health. Mar 1998;52(3):153-160.

14. Hill K, Kaplan HS. Life history traits in humans: theory and empirical studies. Annu Rev Anthropol. 1999;28:397-430.

15. Low BS. Why sex matters. Princeton, NJ: Princeton University Press; 2000.

16. Clarke AL, Low BS. Testing Evolutionary Hypotheses with Demographic Data. Population and Development Review. 2001;27(4):633-660.

17. Keizer R, Dykstra PA, Jansen MD. Pathways into childlessness: evidence of gendered life course dynamics

Journal of Biosocial Science. 2007;40:863-878.

18. Caldwell JC. Mass Education as a Determinant of the Timing of Fertility Decline. Population and Development Review. 1980;6(2):225-255.

19. Caldwell JC. The global fertility transition: The need for a unifying theory. Population and Development Review. Dec 1997;23(4):803-+.

20. United Nations. Fertility behaviour in the context of development: evidence from the World Fertility Survey. New York: United Nations; 1987.

21. Endler JA. Natural selection in the wild. Prinvrton, N.J.: Princeton University Press; 1986. 
22. Andersson MS. Sexual selection. Princeton, NJ: Princeton University Press; 1994.

23. Miller GF. Sexual selection for indicators of intelligence. In: Bock G, Goode J, Webb K, eds. The nature of intelligence. Chichester: John Wiley; 2000:260275.

24. Buss DM. Sex differences in human mate selection: Evolutionary hypotheses tested in 37 cultures. Behav Brain Sci. 1989;12(1):1-49.

25. Buunk BP, Dijkstra P, Fetchenhauer D, Kenrick DT. Age and Gender Differences in Mate Selection Criteria for Various Involvement Levels. Personal Relationships. 2002;9:271-278.

26. Kenrick DT, Sadalla EK, Groth G, Trost MR. Evolution, traits and the stages of human courtship: Qualifying the parental investment model. Journal of Personality. 1990;58:97-117.

27. Li NP, Bailey JM, Kenrick DT, Linsenmeier JAW. The Necessities and Luxuries of Mate Preferences: Testing the Tradeoffs. Journal of Personality and Social Psychology. 2002;82:947-955.

28. Marlowe FW. Mate preferences among Hadza hunter-gatherers. Human Nature. 2004;15(4):365-376.

29. Prokosch MD, Coss RG, Scheib JE, Blozis SA. Intelligence and mate choice: intelligent men are always appealing. Evol Hum Behav. 2009;30(1):11-20.

30. Neiss M, Rowe DC, Rodgers JL. Does education mediate the relationship between IQ and age of first birth? A behavioral genetic analysis. Journal of Biosocial Science. 2002;34:259-275.

31. Retherford RD, Sewell WH. Intelligence and family size reconsidered. Social Biology. 1988;35:1-40.

32. Rodgers JL, Cleveland HH, van den Oord E, Rowe DC. Resolving the debate over birth order, family size, and intelligence. Am Psychol. Jun 2000;55(6):599-612.

33. Goodman A, Koupil I. Social and biological determinants of reproductive success in Swedish males and females born 1915-1929. Evol Hum Behav. 2009;30:329-341.

34. Tannsjö T. Compulsory sterilisation in Sweden. Bioethics. 1998;12(3):236249.

35. Runcis M. Steriliseringar i folkhemmet [Sterilization in the Swedish Welfare State]. Stockholm: Ordfront; 1998.

36. MacCabe JH, Koupil I, Leon DA. Lifetime reproductive output over two generations in patients with psychosis and their unaffected siblings: the Uppsala 1915-1929 Birth Cohort Multigenerational Study. Psychol Med. Oct 2009;39(10):1667-1676.

37. Koupil I. The Uppsala studies on developmental origins of health and disease. J Intern Med. May 2007;261(5):426-436.

38. Statistics Sweden. Meddelanden i samordningsfrågor [Report on co-ordination issues]. Stockholm: Statistics Sweden, 1989: 5; 1989.

39. SOU. Betänkande med utredning och förslag angående betygssättningen $i$ folkskolan [Official report and proposal for elementary school grading]. Stockholm: SOU, 1942: 11; 1942.

40. Husén T, Emanuelsson I, Fagerlind I, Liljefors R. Talent, opportunity and career : a twenty-six year follow-up of 1500 individuals. Stockholm Almqvist \& Wiksell; 1969. 
41. Björklund A. A Comparison Between Actual Distributions of Annual and Lifetime Income: Sweden 1951-1989. The Review of Income and Wealth. 1993;39:377-386.

42. Ohlander A-S. Kvinnor, barn och arbete i Sverige 1850-1993 (Women, children and work in Sweden 1850-1993). Stockholm: Fritzes; 1994.

43. Statistics Sweden. Multi-generational register 2002: A description of contents and quality. Stockholm: Statistiska Centralbyrån; 2003.

44. Borgerhoff Mulder M. The demographic transition: are we any closer to an evolutionary explanation? Trends in Ecology \& Evolution. 1998;13(7):266270.

45. Kaplan H, Lancaster JB, Tucker WT, Anderson KG. Evolutionary approach to below replacement fertility. Am J Hum Biol. Mar-Apr 2002;14(2):233-256.

46. Das Gupta M. Death Clustering, Mothers' Education and the Determinants of Child Mortality in Rural Punjab, India. Population Studies. 1990;44(3):489505.

47. Hoem JM. Educational Gradients in Divorce Risks in Sweden in Recent Decades. Population Studies. 1997;51(1):19-27.

48. Bernhardt E. Cohabitation and marriage among young adults in Sweden: attitudes, expectations and plans. Scandinavian Population Studies. 2002;13:157-170.

49. Sprecher S, Sullivan Q, Hatfield E. Mate Selection Preferences: Gender Differences Examined in a National Sample. Journal of Personality and Social Psychology. 1994;66(6):1074-1080.

50. Nettle D, Pollet TV. Natural selection on male wealth in humans. American Naturalist. 2008;172:658-666.

51. Hopcroft RL. Sex status and reproductive success in the contemporary United States. Evol Hum Behav. 2006;27:104-120.

52. Fieder M, Huber S. The effects of sex and childlessness on the association between status and reproductive output in modern society. Evol Hum Behav. 2007;28:392-398.

53. Vågerö D, Modin B. Prenatal growth, subsequent marital status, and mortality: longitudinal study. Bmj. Feb 16 2002;324(7334):398.

54. Phillips DI, Handelsman DJ, Eriksson JG, Forsen T, Osmond C, Barker DJ. Prenatal growth and subsequent marital status: longitudinal study. BMJ. Mar 31 2001;322(7289):771. 


\section{Appendix: Supplementary Material}

Supplementary, Table 4: Univariable association with total number of children and grandchildren among 5244 males and 4863 females from the Uppsala Birth cohort (born 19151929; analyses restricted to those who survived to age 15 and did not permanently emigrate)

\begin{tabular}{|c|c|c|c|c|c|c|c|c|c|c|}
\hline & & \multicolumn{3}{|c|}{ Total sample } & \multicolumn{3}{|l|}{ Males } & \multicolumn{3}{|c|}{ Females } \\
\hline & & $\mathbf{N}$ & $\begin{array}{l}\text { Mean } \\
\text { no. } \\
\text { childre } \\
\text { n }\end{array}$ & $\begin{array}{l}\text { Mean } \\
\text { no. } \\
\text { grand } \\
\text { childr } \\
\text { en }\end{array}$ & $\mathbf{N}$ & $\begin{array}{l}\text { Mean } \\
\text { no. } \\
\text { childr } \\
\text { en }\end{array}$ & $\begin{array}{l}\text { Mean } \\
\text { no. } \\
\text { grandc } \\
\text { hildren }\end{array}$ & $\mathbf{N}$ & $\begin{array}{l}\text { Mean } \\
\text { no. } \\
\text { childre } \\
\text { n }\end{array}$ & $\begin{array}{l}\text { Mean } \\
\text { no. } \\
\text { grandc } \\
\text { hildren }\end{array}$ \\
\hline Full sample & & 10,107 & 1.83 & 3.37 & 5244 & 1.79 & 3.24 & 4863 & 1.87 & 3.53 \\
\hline Sex & $\begin{array}{l}\text { Male } \\
\text { Female } \\
\text { p-value for heterogeneity }\end{array}$ & $\begin{array}{l}5244 \\
4863\end{array}$ & $\begin{array}{r}1.79 \\
1.87 \\
0.004 \\
\end{array}$ & $\begin{array}{r}3.24 \\
3.53 \\
<0.001 \\
\end{array}$ & $\begin{array}{r}5244 \\
-\end{array}$ & $\begin{array}{r}1.79 \\
- \\
-\end{array}$ & $\begin{array}{r}3.24 \\
- \\
-\end{array}$ & $\begin{array}{r}- \\
4863\end{array}$ & $\begin{array}{r}- \\
1.87 \\
-\end{array}$ & $\begin{array}{r}3.53 \\
- \\
\end{array}$ \\
\hline $\begin{array}{l}\text { School } \\
\text { marks }\end{array}$ & $\begin{array}{l}\text { Quintile } 1 \text { (highest) } \\
\text { Quintile } 2 \\
\text { Quintile } 3 \\
\text { Quintile } 4 \\
\text { Quintile } 5 \text { (lowest) } \\
\text { p-value for heterogeneity } \\
\text { p-value for linear term } \\
\text { p-value for interaction } \\
\text { linear and gender }\end{array}$ & $\begin{array}{l}2011 \\
2023 \\
2027 \\
2055 \\
1991\end{array}$ & $\begin{array}{r}1.91 \\
1.85 \\
1.84 \\
1.80 \\
1.76 \\
0.04 \\
0.001 \\
0.04\end{array}$ & $\begin{array}{l}3.50 \\
3.40 \\
3.32 \\
3.33 \\
3.34 \\
0.51 \\
0.09 \\
0.06\end{array}$ & $\begin{array}{r}822 \\
916 \\
1022 \\
1157 \\
1327\end{array}$ & $\begin{array}{r}1.90 \\
1.80 \\
1.86 \\
1.74 \\
1.71 \\
0.02 \\
<0.001\end{array}$ & $\begin{array}{l}3.40 \\
3.25 \\
3.26 \\
3.14 \\
3.20 \\
0.60 \\
0.06\end{array}$ & $\begin{array}{r}651 \\
885 \\
990 \\
1095 \\
1169\end{array}$ & $\begin{array}{l}1.91 \\
1.88 \\
1.83 \\
1.88 \\
1.87 \\
0.81 \\
0.43\end{array}$ & $\begin{array}{l}3.56 \\
3.53 \\
3.39 \\
3.57 \\
3.62 \\
0.63 \\
0.60\end{array}$ \\
\hline $\begin{array}{l}\text { Age started } \\
\text { third grade } \dagger\end{array}$ & $\begin{array}{l}\text { 1-2 years ahead } \\
\text { Correct age } \\
1 \text { year behind } \\
2-5 \text { years behind } \\
\text { p-value for heterogeneity } \\
\text { p-value for interaction } \\
\text { with gender }\end{array}$ & $\begin{array}{r}259 \\
8129 \\
1501 \\
200\end{array}$ & $\begin{array}{r}2.09 \\
1.85 \\
1.73 \\
1.46 \\
<0.001 \\
\\
0.005\end{array}$ & $\begin{array}{r}3.60 \\
3.42 \\
3.25 \\
2.55 \\
0.002 \\
\\
0.08\end{array}$ & $\begin{array}{r}143 \\
4105 \\
861 \\
126\end{array}$ & $\begin{array}{r}2.13 \\
1.82 \\
1.63 \\
1.34 \\
<0.001\end{array}$ & $\begin{array}{r}3.68 \\
3.29 \\
3.06 \\
2.29 \\
0.001\end{array}$ & $\begin{array}{r}116 \\
3971 \\
623 \\
71\end{array}$ & $\begin{array}{l}2.03 \\
1.88 \\
1.87 \\
1.66 \\
0.44\end{array}$ & $\begin{array}{l}3.51 \\
3.55 \\
3.50 \\
3.01 \\
0.64\end{array}$ \\
\hline $\begin{array}{l}\text { Recognised } \\
\text { learning } \\
\text { difficulty }\end{array}$ & $\begin{array}{l}\text { No } \\
\text { Yes } \\
\text { p-value for heterogeneity } \\
\text { p-value for interaction } \\
\text { with gender }\end{array}$ & $\begin{array}{r}9991 \\
116\end{array}$ & $\begin{array}{r}1.84 \\
1.38 \\
0.001 \\
0.26\end{array}$ & $\begin{array}{l}3.39 \\
2.66 \\
0.03 \\
0.50\end{array}$ & $\begin{array}{r}5179 \\
65\end{array}$ & $\begin{array}{r}1.80 \\
1.20 \\
0.002\end{array}$ & $\begin{array}{l}3.25 \\
2.34 \\
0.03\end{array}$ & $\begin{array}{r}4741 \\
49\end{array}$ & $\begin{array}{l}1.88 \\
1.60 \\
0.25\end{array}$ & $\begin{array}{l}3.53 \\
3.08 \\
0.46\end{array}$ \\
\hline
\end{tabular}

$\dagger$ Missing data on age in third grade $(0.2 \%)$ means that the number of individuals adds up to less than 10,107 for this variable. P-values calculated adjusting for birthyear by 1-year age band. 
Supplementary, Table 5: Univariable association with ever marrying, among 4892 males and 4639 females from the Uppsala Birth cohort (born 1915-1929; analyses restricted to those who survived to age 50 and did not permanently emigrate)

\begin{tabular}{|c|c|c|c|c|c|c|c|}
\hline & & \multicolumn{2}{|c|}{$\begin{array}{l}\text { Total } \\
\text { population }\end{array}$} & \multicolumn{2}{|l|}{ Males } & \multicolumn{2}{|l|}{ Females } \\
\hline & & $\mathbf{N}$ & $\begin{array}{l}\text { \% Ever } \\
\text { marry }\end{array}$ & $\mathbf{N}$ & $\begin{array}{l}\text { \% Ever } \\
\text { marry }\end{array}$ & $\mathbf{N}$ & $\begin{array}{l}\text { \% Ever } \\
\text { marry }\end{array}$ \\
\hline Full sample & & 9531 & 91.1 & 4892 & 89.7 & 4639 & 92.7 \\
\hline Sex & $\begin{array}{l}\text { Male } \\
\text { Female } \\
\text { p-value for heterogeneity }\end{array}$ & $\begin{array}{l}4892 \\
4639\end{array}$ & $\begin{array}{r}89.7 \\
92.7 \\
<0.001 \\
\end{array}$ & $\begin{array}{r}4892 \\
-\end{array}$ & $\begin{array}{r}89.7 \\
-\end{array}$ & 4639 & 92.7 \\
\hline $\begin{array}{l}\text { School } \\
\text { marks }\end{array}$ & $\begin{array}{l}\text { Quintile } 1 \text { (highest) } \\
\text { Quintile } 2 \\
\text { Quintile } 3 \\
\text { Quintile } 4 \\
\text { Quintile } 5 \text { (lowest) } \\
\text { p-value for heterogeneity } \\
\text { p-value for linear term } \\
\text { p-value for interaction } \\
\text { linear term and gender }\end{array}$ & $\begin{array}{l}1912 \\
1917 \\
1906 \\
1944 \\
1852\end{array}$ & $\begin{array}{r}92.7 \\
92.3 \\
91.9 \\
91.0 \\
87.7 \\
<0.001 \\
<0.001 \\
<0.001 \\
\end{array}$ & $\begin{array}{r}781 \\
853 \\
946 \\
1084 \\
1228\end{array}$ & $\begin{array}{r}92.5 \\
92.2 \\
91.0 \\
89.4 \\
85.4 \\
<0.001 \\
<0.001\end{array}$ & $\begin{array}{r}1131 \\
1064 \\
960 \\
860 \\
624\end{array}$ & $\begin{array}{l}92.7 \\
92.3 \\
92.9 \\
93.1 \\
92.3 \\
0.96 \\
0.81\end{array}$ \\
\hline $\begin{array}{l}\text { Age in } \\
\text { third grade }\end{array}$ & $\begin{array}{l}1-2 \text { years ahead } \\
\text { Correct age } \\
1 \text { year behind } \\
2-5 \text { years behind } \\
\text { p-value for heterogeneity } \\
\text { p-value for interaction } \\
\text { with gender }\end{array}$ & $\begin{array}{r}243 \\
7694 \\
1395 \\
182\end{array}$ & $\begin{array}{r}92.6 \\
92.3 \\
86.0 \\
79.7 \\
<0.001 \\
\\
0.001 \\
\end{array}$ & $\begin{array}{r}131 \\
3843 \\
797 \\
112\end{array}$ & $\begin{array}{r}95.4 \\
91.5 \\
82.1 \\
75.0 \\
<0.001\end{array}$ & $\begin{array}{r}112 \\
3851 \\
598 \\
70\end{array}$ & $\begin{array}{l}89.3 \\
93.1 \\
91.3 \\
87.1 \\
0.06\end{array}$ \\
\hline $\begin{array}{l}\text { Recognised } \\
\text { learning } \\
\text { difficulty }\end{array}$ & $\begin{array}{l}\text { No } \\
\text { Yes } \\
\text { p-value for heterogeneity } \\
\text { p-value for interaction } \\
\text { with gender }\end{array}$ & $\begin{array}{r}9428 \\
103\end{array}$ & $\begin{array}{r}91.3 \\
75.7 \\
<0.001 \\
\\
0.046 \\
\end{array}$ & $\begin{array}{r}4834 \\
58\end{array}$ & $\begin{array}{r}90.0 \\
65.5 \\
<0.001\end{array}$ & $\begin{array}{r}4594 \\
45\end{array}$ & $\begin{array}{l}92.7 \\
88.9 \\
0.39\end{array}$ \\
\hline
\end{tabular}

$\dagger$ Missing data for age in third grade (0.2\%) means that the number of individuals adds up to less than 9531 for this variable. P-values calculated adjusting for birthyear by 1-year age band. 
Supplementary, Table 6: Sex-stratified analyses of pathways to reproductive success among 5244 males and 4863 females from the Uppsala Birth cohort (born 1915-1929; analyses restricted to those who survived to age 15 and did not permanently emigrate)

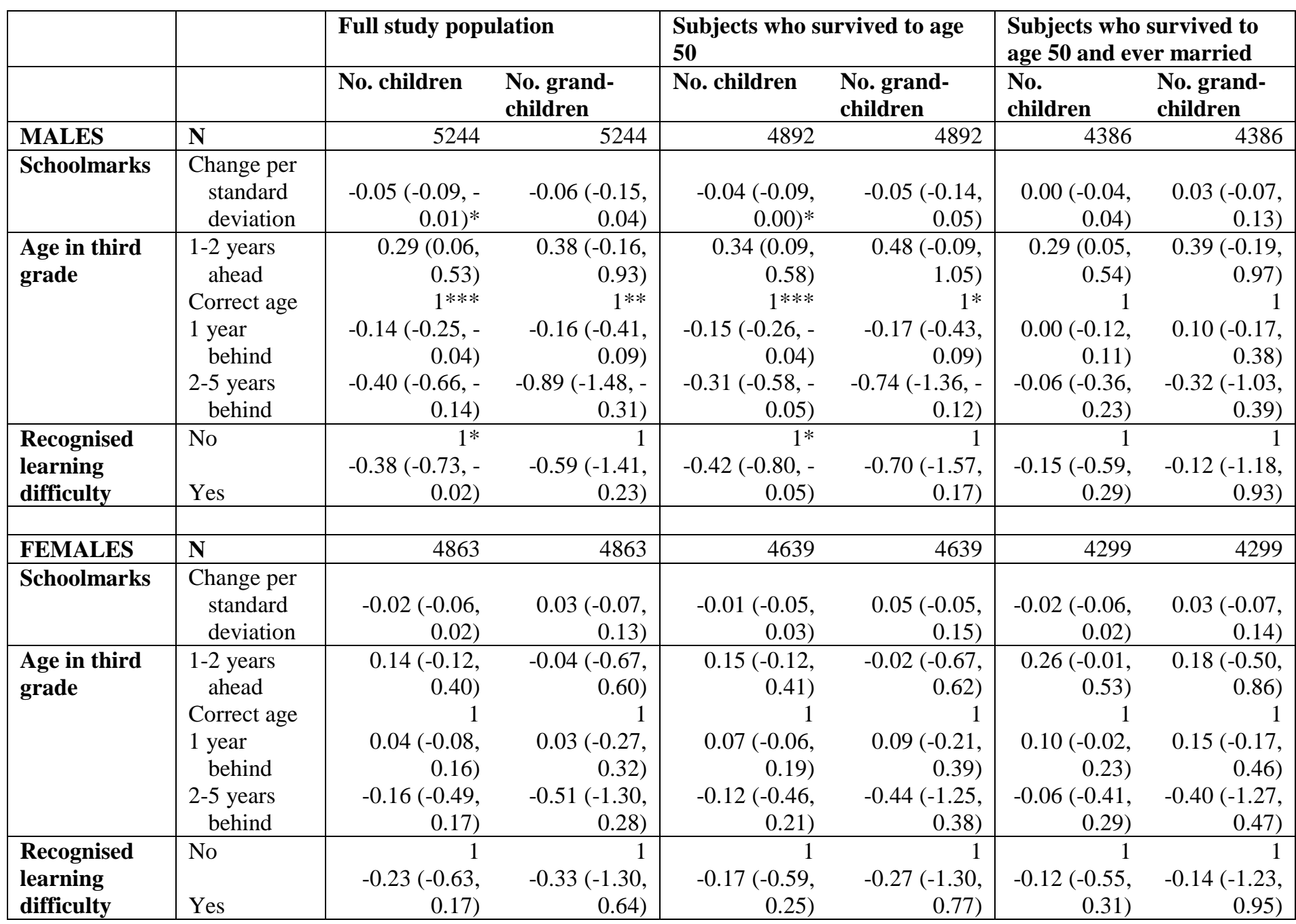

$* \mathrm{p}<0.05, * * \mathrm{p}<0.01, * * * \mathrm{p}<0.001$. All analyses use logistic regression and adjust for year of birthyear by 1 -year age band. All p-values are from tests for heterogeneity, except for the continuous measure of schoolmarks. 
Supplementary, Table 7: Sex-stratified analyses predicting to ever marrying among 4892males and 4639 females from the Uppsala Birth cohort (born 1915-1929; analyses restricted to those who survived to age 50 and did not permanently emigrate)

\begin{tabular}{|c|c|c|c|c|c|c|c|}
\hline & & \multicolumn{3}{|l|}{ MALES } & \multicolumn{3}{|l|}{ FEMALES } \\
\hline & & $\begin{array}{l}\text { Birth } \\
\text { characteristics } \\
\text { only }\end{array}$ & $\begin{array}{l}\text { School } \\
\text { performance } \\
\text { only }\end{array}$ & $\begin{array}{l}\text { Birth characters } \\
\text { plus school } \\
\text { performance }\end{array}$ & $\begin{array}{l}\text { Birth characteristics } \\
\text { only }\end{array}$ & $\begin{array}{l}\text { School performance } \\
\text { only }\end{array}$ & $\begin{array}{l}\text { Birth characters } \\
\text { plus school } \\
\text { performance }\end{array}$ \\
\hline \multicolumn{2}{|l|}{$\mathbf{N}$} & 4892 & 4892 & 4892 & 4639 & 4639 & 4639 \\
\hline \multirow{5}{*}{$\begin{array}{l}\text { Standardised } \\
\text { birthweight for } \\
\text { gestational age }\end{array}$} & Quintile 1 (smallest) & $1 * * *$ & & $1 * *$ & 1 & & 1 \\
\hline & Quintile 2 & $1.39(1.05,1.86)$ & & $1.37(1.02,1.83)$ & $0.78(0.55,1.11)$ & & $0.77(0.54,1.10)$ \\
\hline & Quintile 3 & $1.90(1.40,2.57)$ & & $1.79(1.31,2.44)$ & $1.19(0.81,1.74)$ & & $1.16(0.79,1.71)$ \\
\hline & Quintile 4 & $1.63(1.21,2.20)$ & & $1.52(1.12,2.06)$ & $0.84(0.59,1.21)$ & & $0.82(0.57,1.18)$ \\
\hline & Quintile 5 (largest) & $1.62(1.21,2.18)$ & & $1.49(1.11,2.01)$ & $1.06(0.72,1.57)$ & & $1.03(0.70,1.52)$ \\
\hline \multirow[t]{3}{*}{ Preterm birth } & Term & $1[\mathrm{p}=0.07]$ & & 1 & 1 & & 1 \\
\hline & Preterm & $0.83(0.58,1.19)$ & & $0.89(0.62,1.29)$ & $1.01(0.65,1.59)$ & & $1.02(0.65,1.61)$ \\
\hline & Very preterm & $0.36(0.14,0.92)$ & & $0.45(0.17,1.21)$ & $2.33(0.31,17.78)$ & & $2.40(0.32,18.23)$ \\
\hline \multirow[t]{2}{*}{ Birth multiplicity } & Singleton & 1 & & 1 & 1 & & 1 \\
\hline & Twin/triplet & $1.05(0.57,1.91)$ & & $1.18(0.64,2.17)$ & $0.81(0.43,1.54)$ & & $0.87(0.46,1.64)$ \\
\hline \multirow{4}{*}{$\begin{array}{l}\text { Birth order } \\
\text { (mother's parity) }\end{array}$} & 1 & 1 & & 1 & $1 * * *$ & & $1 * * *$ \\
\hline & $2-3$ & $0.81(0.64,1.04)$ & & $0.89(0.70,1.15)$ & $1.70(1.30,2.23)$ & & $1.71(1.30,2.24)$ \\
\hline & $4-5$ & $0.82(0.59,1.14)$ & & $0.99(0.71,1.38)$ & $2.06(1.37,3.11)$ & & $2.14(1.42,3.24)$ \\
\hline & $6-18$ & $0.85(0.57,1.27)$ & & $1.10(0.73,1.66)$ & $2.92(1.75,4.87)$ & & $3.03(1.81,5.06)$ \\
\hline \multirow{6}{*}{$\begin{array}{l}\text { Mother's age } \\
\text { at birth }\end{array}$} & 15-19 years & $1 *$ & & $1 * *$ & $1 * * *$ & & $1 * * *$ \\
\hline & $20-24$ years & $0.85(0.51,1.41)$ & & $0.84(0.50,1.41)$ & $0.36(0.16,0.81)$ & & $0.36(0.16,0.81)$ \\
\hline & 25-29 years & $0.55(0.32,0.93)$ & & $0.54(0.31,0.92)$ & $0.25(0.11,0.56)$ & & $0.25(0.11,0.56)$ \\
\hline & $30-34$ years & $0.62(0.36,1.08)$ & & $0.60(0.34,1.05)$ & $0.22(0.09,0.50)$ & & $0.22(0.09,0.51)$ \\
\hline & 35-39 years & $0.49(0.27,0.88)$ & & $0.47(0.26,0.85)$ & $0.18(0.08,0.44)$ & & $0.19(0.08,0.44)$ \\
\hline & $40-49$ years & $0.47(0.24,0.92)$ & & $0.45(0.23,0.88)$ & $0.16(0.06,0.40)$ & & $0.16(0.06,0.41)$ \\
\hline \multirow{2}{*}{$\begin{array}{l}\text { Mother's marital } \\
\text { status }\end{array}$} & Never married & 1 & & 1 & 1 & & 1 \\
\hline & Ever married & $0.71(0.52,0.97)$ & & $0.78(0.57,1.06)$ & $1.06(0.71,1.57)$ & & $1.07(0.71,1.60)$ \\
\hline \multirow{7}{*}{$\begin{array}{l}\text { Family social } \\
\text { class at } \\
\text { birth }\end{array}$} & High/mediate non-manuals & $1 * *$ & & $1 * *$ & 1 & & 1 \\
\hline & Lower non-manuals & $0.67(0.36,1.25)$ & & $0.72(0.37,1.39)$ & $1.15(0.68,1.94)$ & & $1.14(0.65,1.98)$ \\
\hline & Skilled manuals & $0.57(0.33,0.98)$ & & $0.68(0.39,1.17)$ & $1.83(1.14,2.93)$ & & $1.82(1.11,3.00)$ \\
\hline & Unskilled manuals & $0.46(0.28,0.76)$ & & $0.55(0.33,0.93)$ & $1.48(0.99,2.21)$ & & $1.49(0.98,2.28)$ \\
\hline & Entrepreneurs & $0.70(0.33,1.49)$ & & $0.76(0.35,1.64)$ & $1.27(0.65,2.49)$ & & $1.25(0.62,2.55)$ \\
\hline & Farmers & $0.39(0.23,0.65)$ & & $0.43(0.25,0.74)$ & $1.40(0.88,2.23)$ & & $1.39(0.87,2.24)$ \\
\hline & House son/daughter & $0.33(0.17,0.65)$ & & $0.38(0.18,0.78)$ & $1.02(0.51,2.02)$ & & $1.01(0.50,2.07)$ \\
\hline
\end{tabular}




\begin{tabular}{|c|c|c|c|c|c|}
\hline Schoolmarks & Change per standard deviation & $\begin{array}{r}0.79(0.71, \\
0.88)^{* * * *} \\
\end{array}$ & $0.79(0.72,0.88)^{* * *}$ & $1.03(0.92,1.15)$ & $0.98(0.87,1.10)$ \\
\hline \multirow[t]{4}{*}{ Age in third grade } & $1-2$ years ahead & $1.80(0.79,4.14)$ & $1.44(0.62,3.38)$ & $0.60(0.33,1.12)$ & $0.82(0.43,1.56)$ \\
\hline & Correct age & $1 * * *$ & $1 * * *$ & 1 & 1 \\
\hline & 1 year behind & $0.49(0.39,0.62)$ & $0.51(0.41,0.65)$ & $0.80(0.58,1.10)$ & $0.77(0.55,1.06)$ \\
\hline & $2-5$ years behind & $0.35(0.22,0.55)$ & $0.39(0.24,0.62)$ & $0.51(0.25,1.05)$ & $0.51(0.24,1.07)$ \\
\hline Recognised & No & $1 * *$ & $1 * *$ & 1 & 1 \\
\hline learning difficulty & Yes & $0.40(0.22,0.71)$ & $0.37(0.20,0.66)$ & $0.81(0.31,2.14)$ & $0.79(0.29,2.15)$ \\
\hline
\end{tabular}

$* \mathrm{p}<0.05, * * \mathrm{p}<0.01, * * * \mathrm{p}<0.001$. All analyses use logistic regression and adjust for year of birthyear by 1 -year age band. All $\mathrm{p}$-values are from tests for heterogeneity, except for the continuous measure of schoolmarks. 